\title{
Nursing responsibilities for rotablation
}

\section{Kristijana Radić*, Biljana Šego, Mirjana Slanc}

University Hospital Dubrava, Zagreb, Croatia
KEYWORDS: rotablation, nurse competency.

CITATION: Cardiol Croat. 2018;13(1-2):46. | https://doi.org/10.15836/ccar2018.46

*ADDRESS FOR CORRESPONDENCE: Kristijana Radić, Klinička bolnica Dubrava, Avenija Gojka Šuška 6, HR-10000 Zagreb, Croatia. / Phone: +385-99-3535-008 / E-mail: kristijana.radic41@gmail.com

ORCID: Kristijana Radić, https://orcid.org/0000-0002-6098-254X • Biljana Šego, https://orcid.org/0000-0002-3229-9436

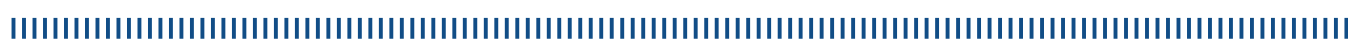

Rotational atherectomy is used in patients with highly calcified coronary arteries where it is very hard to perform percutaneous transluminal coronary angioplasty (PTCA) procedures. ${ }^{1,2}$ Operating nurses have to know all phases of the procedure, anatomy and physiology, usage of aseptic methods. Importance of the work process in the operating room, high level of professional education, knowing skills of high-quality maintain high quality of health care is a must-have in these procedures.

Rotablation represents an addition to the standard PTCA procedure, it makes treatment of calcified vessels easier and less risky. Nurse is responsible for assembling and material integrity. She needs to cooperate and support the interventional cardiologist, notify and check for ECG changes. Important responsibilities of nurse before rotablation are:

1. System set-up:

- Connect foot pedal to console

- Connect air hose to air supply

- Connect air supply to console

- Open gas tank to pressurize system

2. Rotablation flushing cocktail: verapamil, nitrates and heparin in saline

3. Component set-up:

- Attach advancer to the console

- Attach saline infusion port to IV pressure bag

- Open irrigation line

- Backload burr catheter into guidewire

- Connect wire clip torquer

4. Pre-procedure system test - DRAW test:

- $\mathrm{D}$ - Drip = Verify irrigation at distal tip of burr catheter

- $\mathrm{R}-$ Rotation = set burr speed to desired RPM level and verify Dynaglyde speed

- A - Advancement = Confirm advancer knob and burr move freely

- $\mathrm{W}$ - Wire = Verify brake is holding guidewire while burr is spinning, and wire clip is fixed

\section{RECEIVED:}

February 4, 2018

ACCEPTED:

February 10, 2018

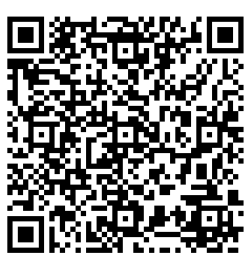

$\square$ Cardiologia Croatica 2018;13(1-2):46.
VIII. nacionalni sastanak o kardiovaskularnim intervencijama s međunarodnim sudjelovanjem VII. sastanak intervencijskih kardioloških medicinskih sestara i tehničara

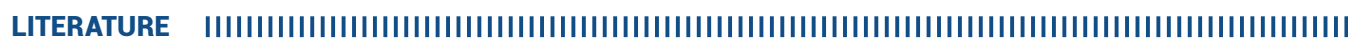

1. Mintz GS, Popma JJ, Pichard AD, Kent KM, Satler LF, Chuang YC, et al. Patterns of calcification in coronary artery disease. A statistical analysis of intravascular ultrasound and coronary angiography in 1155 lesions. Circulation. 1995 Apr 1;917):1959-65. https://doi.org/10.1161/01.CIR.91.7.1959

2. Astin F, Carroll DL, Ruppar T, Uchmanowicz I, Hinterbuchner L, Kletsiou E, et al; Education Committee of the Council on Cardiovascular Nursing and Allied Professions. A core curriculum for the continuing professional development of nurses: Developed by the Education Committee on behalf of the Council on Cardiovascular Nursing and Allied Professions of the ESC. Eur J Cardiovasc Nurs. 2015 Jun;14(3):190-7. https://doi.org/10.1177/1474515115572048 